\title{
Autotrophic and mixotrophic growth of Gallionella ferruginea
}

\author{
LotTa HallbecK* and Karsten Pedersen \\ Department of General and Marine Microbiology, University of Göteborg, Carl Skottsbergs gata 22, \\ S-413 19 Göteborg, Sweden
}

(Received 23 May 1991; revised 24 July 1991; accepted 26 July 1991)

\begin{abstract}
$\mathrm{CO}_{2}$ fixation and uptake of sugars by Gallionella ferruginea were demonstrated by liquid scintillation and microautoradiographic techniques. The theoretical carbon content of a $G$. ferruginea cell in the exponential and stationary growth phases was calculated from size measurements of images of acridine-orange-stained cells. The carbon content of a cell in the exponential phase was $1.25 \times 10^{-14} \mathrm{~mol}$ and for a cell in the stationary phase it was $5 \times 10^{-15} \mathrm{~mol}$. $G$. ferruginea was shown to obtain all of its cell carbon from $\mathrm{CO}_{2}$ fixation when it was cultured under aerobic gradient conditions in a mineral salt solution with iron sulphide. Uptake experiments were performed with 1.6 $\mu \mathrm{M}-\left[{ }^{14} \mathrm{C} \mid g l u c o s e, 1.6 \mu \mathrm{M}-\left[{ }^{14} \mathrm{C} \mid\right.\right.$ fructose and 1.3 $\mu \mathrm{M}-\left[{ }^{14} \mathrm{C}\right]$ sucrose. There was significant uptake of all three sugars. Measurements of respired ${ }^{14} \mathrm{CO}_{2}$ showed that $48 \%, 25 \%$ and $32 \%$ of the total amount of incorporated sugar was respired for glucose, fructose and sucrose, respectively. The uptake of glucose increased when the glucose concentration in the growth medium was increased. At a glucose concentration of $10 \mu \mathrm{M}$ or higher, the cell carbon was derived exclusively from glucose, within the errors of estimation. Mixotrophic growth with $20 \mu \mathrm{M}$ glucose decreased the $\mathrm{CO}_{2}$ fixation to $0.4 \times 10^{-14}$ mol carbon per cell, compared to autotrophically grown cells with $1.0 \times 10^{-14} \mathrm{~mol}$ carbon per cell. The addition of $20 \mu \mathrm{M}$-glucose gave an increase in cell number in the stationary phase from $1 \times 10^{6}$ to $5 \times 10^{6}$ cells ml-1. $^{-1}$.
\end{abstract}

\section{Introduction}

The carbon source for Gallionella ferruginea has been thought to be $\mathrm{CO}_{2}$ ever since Winogradsky (1922) stated, but did not demonstrate, that this organism is an ironoxidizing, autotrophic bacterium (Brock \& Schlegel, 1989). Hanert (1989) reported the presence of ribulose1,5-bisphosphate carboxylase in $G$. ferruginea, but there is still no unequivocal proof for autotrophic growth by this organism (Jorgensen, 1989). This is probably because the organism is notoriously difficult to work with - it grows slowly, with a generation time of $8 \mathrm{~h}$, to, at most, $2 \times 10^{6}$ cells $\mathrm{ml}^{-1}$ in a liquid mineral medium (Hallbeck \& Pedersen, 1990). Most textbooks on microbiology therefore still describe $G$. ferruginea as a stalk-forming iron bacterium with an uncertain carbon metabolism (e.g. Brock \& Madigan, 1988; Stanier et al., 1989).

Mixotrophic organisms can obtain energy, carbon or both from inorganic and organic substrates and $\mathrm{CO}_{2}$ (Kelly, 1989). The regulatory mechanism of mixotrophy tends to avoid the energetically more expensive $\mathrm{CO}_{2}$

Abbreviations: AODC, acridine orange direct count; MSS, mineral salts solution; $n$, number of experiments. fixation under more favourable nutritional conditions (Bowien et al., 1987). G. ferruginea has been thought to be an obligate autotroph without the ability to grow as a mixotroph (Lütters-Czekalla, 1990).

This work demonstrates $\mathrm{CO}_{2}$ fixation and incorporation of glucose, fructose and sucrose by $G$. ferruginea with ${ }^{14} \mathrm{C}$-labelled compounds, measured by liquid scintillation and microautoradiographic techniques. Mixotrophic growth on glucose was demonstrated as a simultaneous increase in the proportion of the cell carbon assimilated from $\left[{ }^{14} \mathrm{C}\right]$ glucose and a decrease in the $\mathrm{CO}_{2}$ fixation, when the glucose concentration in the culture medium was increased. Weight and carbon content of $G$. ferruginea cells were calculated from cell size measurements of epifluorescence images.

\section{Methods}

Organism and cultural procedures. G. ferruginea, enriched from a 60m-deep drinking-water well (Hallbeck \& Pedersen, 1990), was cultured under aerobic gradient conditions in the mineral salt solution (MSS) with iron sulphide, described by Kucera \& Wolfe (1957) and modified by Hanert (1981). The MSS consists of $1 \mathrm{~g} \mathrm{NH}_{4} \mathrm{Cl}, 0.4 \mathrm{~g} \mathrm{MgSO}_{4} .7 \mathrm{H}_{2} \mathrm{O}$, $0.1 \mathrm{~g} \mathrm{CaCl}_{2} .2 \mathrm{H}_{2} \mathrm{O}$ and $0.05 \mathrm{~g} \mathrm{~K}_{2} \mathrm{HPO}_{4}$ in 1 litre deionized water. It was 
autoclaved at $121^{\circ} \mathrm{C}$ for $20 \mathrm{~min}$, chilled to $5^{\circ} \mathrm{C}$ and infused with $\mathrm{CO}_{2}$ to $\mathrm{pH} 4 \cdot 6-4 \cdot 8$. Sterile screw-capped tubes $(180 \times 16 \mathrm{~mm})$ were used as culture vessels. These were filled with MSS, which was added through a $0.2 \mu \mathrm{m}$ Dynagard hollow-fibres syringe filter, and 20 drops of a sterile FeS solution were added to give an initial $\mathrm{Fe}^{2+}$ concentration of $0.05 \mathrm{M}$. The volume of the growth medium in the tubes was adjusted to $10 \mathrm{ml}$ after appropriate additions of the carbon sources studied.

Measurement of growth. Batches of culture tubes were prepared for each experiment. The culture tubes were inoculated with 3-4-d-old cells in the late exponential growth phase. The inoculum volume was $0.1 \mathrm{ml}$ and the starting cell concentration was adjusted to $1-2 \times 10^{3}$ cells ml $^{-1}$. Growth was followed using new tubes on every sampling occasion.

Total number of cells. Acridine orange direct count (AODC) (Hobbie et al., 1977) was used to determine the total number of cells in the culture tubes. At least 400 cells or a minimum of 15 microscopic fields $\left(0.0064 \mathrm{~mm}^{2}\right.$ each) were counted on each filter. This method estimated the mean value with a precision of approximately $5 \%$ as described by Hallbeck \& Pedersen (1990).

Sampling procedure. The cultures were sampled with sterile Pasteur pipettes, thus leaving the FeS on the bottom of the tube. The sample was diluted to twice its volume with $0.1 \%$ sterile, filtered oxalic acid, which reduced clogging of the filters by iron precipitates.

Volume, weight and carbon content. The volume of $G$. ferruginea cells in the exponential and stationary growth phases was calculated according to Fry (1990) from epifluorescence microscopy images of cells on Nuclepore filters as follows:

$$
v=\left(d^{2} / 4\right)(l-d)+d^{3} / 6
$$

where $v=$ volume of a cell; $l=$ length of a cell; $d=$ width of a cell. The carbon content of a $G$. ferruginea cell was assumed to be $50 \%$ of the dry weight of a cell with a $70 \%$ water content as shown for cells of Escherichia coli (Ingraham et al., 1983).

Fixation of ${ }^{14} \mathrm{CO}_{2}$. One-millilitre aliquots of $1.8 \mathrm{mM}-\mathrm{NaH}^{14} \mathrm{CO}_{3}$ $\left(2.02 \mathrm{GBq} \mathrm{mmol}^{-1}\right)$ were added to the culture tubes prior to inoculation and incubation. The resulting concentration in the culture tubes was $0.18 \mathrm{~mm}$. The stock solution of $\mathrm{NaH}^{14} \mathrm{CO}_{3}$ was diluted in sterile deionized water, $\mathrm{pH} \mathrm{8.9}$, in a butyl-rubber-stoppered serum bottle. Portions of samples, taken during growth cycles, were filtered onto $0.2 \mu \mathrm{m}$ Nuclepore filters, $13 \mathrm{~mm}$ diameter. The filters were washed with $0.5 \mathrm{ml} 2 \%(\mathrm{v} / \mathrm{v}) \mathrm{HCl}$ and $0.5 \mathrm{ml}$ de-ionized water to remove remaining $\mathrm{HCO}_{3}^{-}$, placed in $10 \mathrm{ml}$ Ready Safe scintillation cocktail (Beckman) in a glass scintillation vial, and the radioactivity measured in a Beckman LS 3801 scintillation counter. Controls for abiotic adsorption of $\mathrm{HCO}_{3}^{-}$on filters and cells were done as follows. Samples from cultures grown for $165 \mathrm{~h}$ were supplemented with $\mathrm{NaH}^{14} \mathrm{CO}_{3}$ to a concentration of $0.18 \mathrm{mM}$, shaken vigorously and then treated as described above. The lowest amount of fixed carbon possible to measure was approximately $10^{-18} \mathrm{~mol}$ fixed $\mathrm{C}$ per cell.

The total amount of fixed carbon per $\mathrm{ml}$ was calculated as follows:

$$
\frac{\text { D.p.m. } \times 1 \cdot 1 \times \sum \mathrm{C}}{A \times N}=\text { mol C fixed per cell and growth cycle }
$$

where d.p.m. $=$ disintegrations $\min ^{-1} \mathrm{ml}^{-1} ; 1 \cdot 1=$ correction for the heavier ${ }^{14} \mathrm{C}$ isotope; $\mathrm{C}=$ total inorganic carbon, $\mathrm{mol} \mathrm{ml}^{-1} ; A=$ total activity of $\mathrm{NaH}^{14} \mathrm{CO}_{3}$ (ml culture) ${ }^{-1} ; N=$ total number of cells $\mathrm{ml}^{-1}$. D.p.m. were counted in a scintillation counter; $\boldsymbol{A}$ was measured in cultures without cells; $\mathrm{C}$ was determined with a $\mathrm{CO}_{2}$ Coulometer model 5011 (Coulometrics Incorporated) (Huffman, 1977); $N$ was determined by AODC.

Incorporation of ${ }^{14} \mathrm{C}$-labelled organic compounds. One-millilitre aliquots of four different ${ }^{14} \mathrm{C}$-labelled organic compounds were added to the culture tubes prior to inoculation: $\left[\mathrm{U}^{-14} \mathrm{C}\right] \mathrm{glucose}, 1 \cdot 6 \mu \mathrm{M}(9 \cdot 1 \mathrm{GBq}$ $\left.\mathrm{mmol}^{-1}\right)$; [U-14 ${ }^{14}$ ] fructose; $1.6 \mu \mathrm{M}\left(11.0 \mathrm{GBq} \mathrm{mmol}^{-1}\right)$; [U-14 $\left.{ }^{14}\right]$ sucrose, $1.3 \mu \mathrm{M}\left(22.0 \mathrm{GBq} \mathrm{mmol}{ }^{-1}\right)$; [U-1 ${ }^{14} \mathrm{C}$ ]formate, $7 \mu \mathrm{M}(2.05 \mathrm{GBq}$ $\mathrm{mmol}^{-1}$ ) (Amersham Sweden). The stock solutions were diluted in sterile MSS. Portions of samples, taken during growth cycles, were filtered onto $0.2 \mu \mathrm{M}$ Nuclepore filters, $13 \mathrm{~mm}$ diameter. The filters were washed with $0.5 \mathrm{ml} 2 \%(\mathrm{v} / \mathrm{v}) \mathrm{HCl}$ and $0.5 \mathrm{ml}$ deionized water to remove eventually respired $\mathrm{HCO}_{3}{ }^{-}$, placed in $10 \mathrm{ml}$ Ready Safe scintillation cocktail (Beckman) in a glass scintillation vial, and the radioactivity measured in a Beckman LS 3801 scintillation counter.

Controls for abiotic adsorption of the ${ }^{14} \mathrm{C}$-labelled compounds on filters and cells were done as described for the experiments with $\mathrm{NaH}^{14} \mathrm{CO}_{3}$, using the compounds at their respective concentrations. The lowest amount of incorporated ${ }^{14} \mathrm{C}$ per cell possible to measure was approximately $10^{-18} \mathrm{~mol}$.

Respired ${ }^{14} \mathrm{CO}_{2}$ from added organic carbon compounds. Cultures were grown for approximately $165 \mathrm{~h}$ to stationary phase in gastight aluminium-crimp-sealed butyl-rubber-stoppered Hungate tubes $(150 \times 18 \mathrm{~mm})$ with labelled organic carbon sources added as above. The ${ }^{14} \mathrm{CO}_{2}$ derived from the respiration of the carbon compounds was subsequently measured with a technique adapted from Nelson et al. (1987). Briefly, the cultures were supplied with $0.1 \mathrm{ml} 0.3 \mathrm{M}-\mathrm{HCl}$ via hypodermic needles through the stoppers, and infused for $10 \mathrm{~min}$ with nitrogen gas that was subsequently passed through $10 \mathrm{ml}$ ethanolamine/methanol $(60: 40, \mathrm{v} / \mathrm{v})$ in two $20 \mathrm{ml}$ butyl-rubber-stoppered vials connected in series. Portions of 0.1 or $1 \mathrm{ml}$ of the mixture with the trapped ${ }^{14} \mathrm{CO}_{2}$ were added to $10 \mathrm{ml}$ Ready Safe scintillation cocktail (Beckman) in glass scintillation vials and the radioactivity measured. Preliminary tests showed that more than $99 \%$ of the ${ }^{14} \mathrm{CO}_{2}$ from the samples were trapped in the first vial.

Organic ${ }^{14} \mathrm{C}$-labelled compounds were added to sterile tubes as above, incubated as the cultures and used as controls for any chemical conversion of the organic compounds to $\mathrm{CO}_{2}$. Measurements were done both with and without $\mathrm{HCl}$ addition.

Microautoradiography. Microautoradiographic studies were done on cells grown with $1.7 \mathrm{mM}-\mathrm{NaH}^{14} \mathrm{CO}_{3}$ and $6.25 \mu \mathrm{M}-\left[{ }^{14} \mathrm{C}\right]$ glucose. The procedure followed was the MARG-E method described by Tabor \& Neihof (1982). Portions of $0.6 \mathrm{ml}$ from sampled and diluted cultures, grown for approximately $165 \mathrm{~h}$, were filtered through Nuclepore filters (pore size $0.2 \mu \mathrm{m}$ ) and rinsed three times with $1 \mathrm{ml}$ filtered deionized water (pore size $0.2 \mu \mathrm{m}$ ). The filters were transferred to clean microscope slides, previously dipped in Kodak NTB-2 autoradiographic emulsion. The slides with the filters were placed in a water-chilled PVC containment $\left(10^{\circ} \mathrm{C}\right)$, and moved to a desiccator after solidifying. They were left for exposure under vacuum over silica gel for $3 \mathrm{~d}$ at $4{ }^{\circ} \mathrm{C}$. Cells that showed at least three silver grains no more than $3 \mu \mathrm{m}$ from the cell were counted as positive for uptake of the labelled compound.

Mixotrophy. Different glucose concentrations $(0 \cdot 1,1 \cdot 0,1 \cdot 3,2 \cdot 0,5 \cdot 0$, $6 \cdot 25,10,15,20$ and $25 \mu \mathrm{M})$ were added as 1 part $\left[{ }^{14} \mathrm{C}\right]$ glucose and 4 parts unlabelled glucose. The cultures were grown for $145-165 \mathrm{~h}$ to the stationary phase prior to sampling and counting as described for incorporation of ${ }^{14} \mathrm{C}$-labelled compounds above.

Cultures were prepared with $0 \cdot 18 \mathrm{mM}-\mathrm{NaH}^{14} \mathrm{CO}_{3}$ as described for fixation of ${ }^{14} \mathrm{C}$ with and without the addition of $20 \mu \mathrm{M}$-unlabelled glucose, sampled and counted as described above.

\section{Results}

\section{Cell volume, weight and carbon content}

The length and width of a cell in the exponential growth phase and in the stationary growth phase 


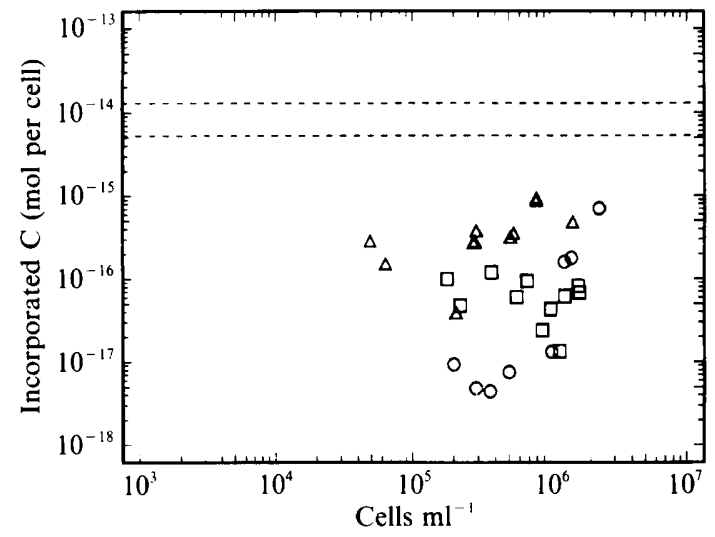

Fig. 1. Relation between total number of cells and mol incorporated carbon from sugars, from growth experiments with $G$. ferruginea and $1.6 \mu \mathrm{M}$-glucose $(\triangle), 1.6 \mu \mathrm{M}$-fructose $(O)$ and $1.3 \mu \mathrm{M}$-sucrose $(\square)$. The dashed lines denote the calculated carbon content interval of a $G$. ferruginea cell during a growth cycle. Data from three experiments per sugar.

were $2.3 \times 0.2 \mu \mathrm{m}, \quad 0.7 \pm 0.1 \mu \mathrm{m}$ and $1.7 \pm 0.1 \mu \mathrm{m}$, $0.6 \pm 0.07 \mu \mathrm{m}$ respectively (mean values of 15 cells $\pm \mathrm{SD}$ ). This gave a cell volume of $1.0 \mu \mathrm{m}^{3}$ for exponential-phase cells and $0.4 \mu \mathrm{m}^{3}$ for stationary-phase cells, from equation (1). The wet weight of one cell was then $1 \times 10^{-12} \mathrm{~g}$ in the exponential phase and $4 \times 10^{-13} \mathrm{~g}$ in the stationary phase, assuming a specific weight of $1 \times 10^{-12} \mathrm{~g}$ per $\mu \mathrm{m}^{3}$ cell. The carbon content of a $G$. ferruginea cell in the exponential phase was calculated to be $1.25 \times 10^{-14} \mathrm{~mol}$ and for a stationary phase cell it was $5 \times 10^{-15} \mathrm{~mol}$.

\section{Fixation of $\mathrm{CO}_{2}$}

The amount of carbon fixed per cell during a growth cycle, calculated from equation (1), was between $6.1 \times 10^{-15} \mathrm{~mol}$ and $3.3 \times 10^{-14} \mathrm{~mol}$ (the number of measurements was nine, distributed between two experiments) and correlated well with the interval that represents the carbon content of $G$. ferruginea during a growth cycle, calculated from the cell size measurements.

\section{Incorporation of ${ }^{14} \mathrm{C}$-labelled organic compounds}

There was a significant uptake of glucose $(1.6 \mu \mathrm{M})$, fructose $(1.6 \mu \mathrm{M})$ and sucrose $(1.3 \mu \mathrm{M})$ by $G$. ferruginea (Fig. 1). The growth rates and the total number of cells at these concentrations of organic substrates did not differ compared to autotrophic growth (Fig. 2). There was also a measurable uptake of formate, but the sterile controls in the respiration experiments showed that there was a significant chemical conversion of formate to $\mathrm{CO}_{2}$. The measured uptake of formate might have originated either

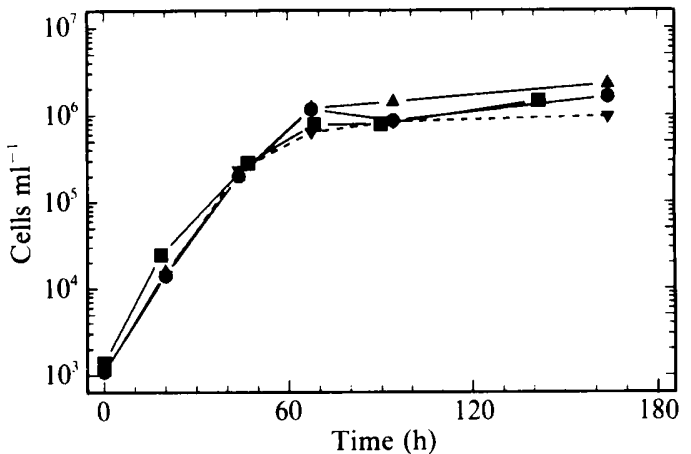

Fig. 2. Growth of $G$. ferruginea under aerobic gradient conditions in MSS with $\mathrm{CO}_{2}$ and FeS. $\Lambda$, With $1.6 \mu \mathrm{M}$-glucose; $\boldsymbol{O}$, with $1.6 \mu \mathrm{M}$ fructose; $\square$, with $1.3 \mu \mathrm{M}$-sucrose; $\nabla$, without addition.

from incorporation of formate or from fixation of ${ }^{14} \mathrm{CO}_{2}$ formed chemically from formate.

\section{Respired ${ }^{14} \mathrm{CO}_{2}$ from organic compounds}

These experiments were performed to confirm that the organic compounds were metabolized. The percentage respired $\mathrm{CO}_{2}$ of the total incorporated carbon (=incorporated and respired carbon) for formate, glucose, fructose and sucrose was $0 \%(\mathrm{SD} \pm 0 \%, n=2), 48 \%$ $(\mathrm{SD} \pm 11 \%, n=7), 25 \%(\mathrm{SD} \pm 8 \%, n=2)$ and $32 \%$ $(\mathrm{SD} \pm 11 \%, n=2)$ respectively.

\section{Microautoradiography}

Radiograms with cells grown with $1.7 \mathrm{~mm}-\mathrm{NaH}^{14} \mathrm{CO}_{3}$ or $6 \cdot 25 \mu \mathrm{M}-\left[{ }^{14} \mathrm{C}\right]$ glucose showed that $97 \%$ (SD $\pm 4 \%$ ) of the population fixed ${ }^{14} \mathrm{CO}_{2}$ and $96 \%(\mathrm{SD} \pm 4 \%)$ of the population incorporated glucose.

\section{Mixotrophic activity}

The amount of carbon incorporated from glucose increased from $2.6 \times 10^{-16}$ to $1.1 \times 10^{-14} \mathrm{~mol}$ per cell, when the glucose concentration was increased from $0 \cdot 1 \mu \mathrm{M}$ to $25 \mu \mathrm{M}$ (Fig. 3). The amount of carbon incorporated from glucose was within the calculated total cell carbon interval at $10 \mu \mathrm{M}$, or higher concentrations of glucose.

When the cultures reached stationary phase, cells grown with $20 \mu \mathrm{M}$-glucose decreased their $\mathrm{CO}_{2}$ fixation to $0.4 \times 10^{-14} \mathrm{~mol}$ carbon per cell, compared to the autotrophically grown cells with $1.0 \times 10^{-14} \mathrm{~mol}$ carbon per cell (Fig. 4). The addition of $20 \mu \mathrm{M}$-glucose also increased the cell number in stationary phase, from $1 \times 10^{6}$ to $5 \times 10^{6}$ cells $\mathrm{ml}^{-1}$ (Fig. 4 ). 


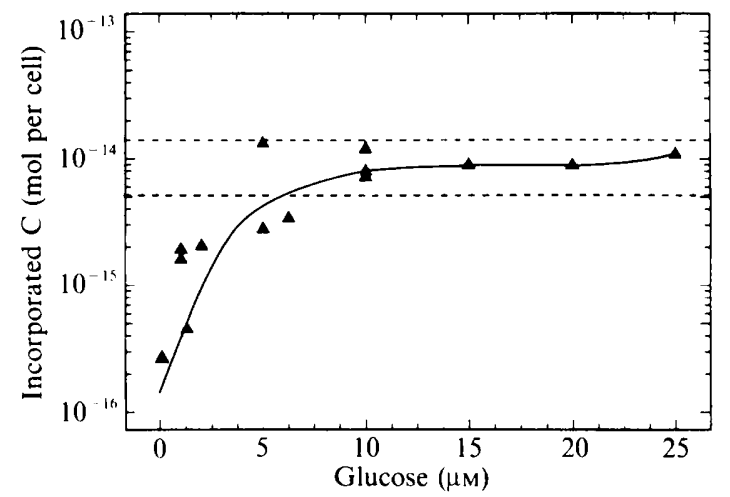

Fig. 3. Incorporated glucose carbon per cell by $G$. ferruginea at $144 \mathrm{~h}$ growth with different glucose concentrations. Dashed lines denote the calculated carbon content interval of a $G$. ferruginea cell during a growth cycle. Data from three experiments.

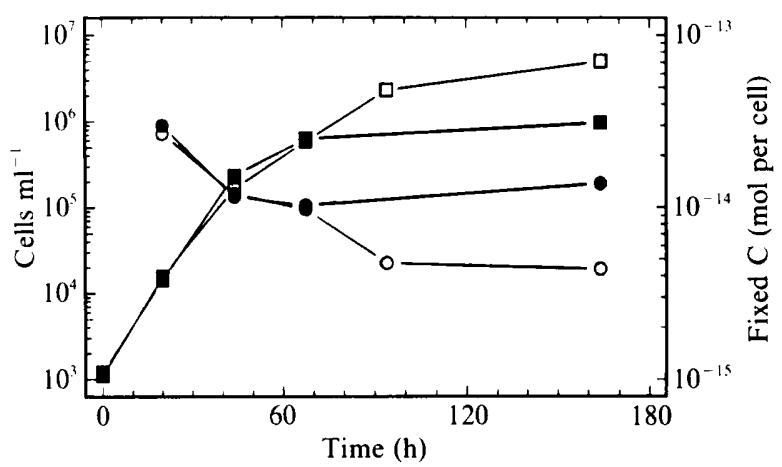

Fig. 4. Growth $(\square, \square)$ and fixed carbon per cell $(\Theta, O)$ by $G$. ferruginea with (open symbols) and without (filled symbols) $20 \mu \mathrm{M}$ glucose.

\section{Discussion}

Gallionella ferruginea grows to a low cell number with stalks heavily encrusted with iron precipitates. This makes both dry weight determination, which is an ordinary method for biomass estimations, and size measurements of cells by light microscopy impossible to use. The use of micrographs of acridine-orange-stained cells for calculation of size and cell volume is a method often used for bacteria in natural habitats and has made size estimations of $G$. ferruginea cells possible. One problem connected with this method could be the socalled 'halo' effect, which makes it difficult to see where the true edge of the bacterium is, and there could also be difficulties in measuring the true central length of a curved rod, but reasonable estimates can be made (Fry, 1990). We have made the size measurements on cells both in the exponential phase and in the stationary phase, and observed that the cell size varies with the cell cycle during the time of growth.

Ribulose-1,5-bisphosphate carboxylase is one of the key enzymes in the reductive pentose phosphate cycle, which is proposed to be the pathway for $\mathrm{CO}_{2}$ fixation used by the majority of the autotrophic eubacteria, to which $G$. ferruginea belongs (Wood, 1989). The presence in $G$. ferruginea of ribulose-1,5-bisphosphate carboxylase has been reported by Hanert (1989), who suggested $G$. ferruginea to be an obligate autotroph. Our study shows that the amount of $\mathrm{CO}_{2}$ fixed by $G$. ferruginea corresponded well with the amount of carbon per cell calculated from size measurements. These results prove that $G$. ferruginea fixes $\mathrm{CO}_{2}$ and further show that the bacterium can obtain all its cell carbon from the fixation of $\mathrm{CO}_{2}$ when it grows in aerobic gradient cultures. The microautoradiography showed that $96 \%$ ( $\mathrm{SD} \pm 4 \%$ ) of the population in the stationary phase had fixed $\mathrm{CO}_{2}$, and demonstrated that the radioactive carbon in the $\mathrm{CO}_{2}$ was incorporated into the cells during the time of the growth experiment.

Acetate, pyruvate, fumarate, succinate, yeast extract and peptone were reported by Lütters-Czekalla (1990) to have no, or a negative, effect on growth of $G$. ferruginea. It was stated, therefore, that $G$. ferruginea is an obligate chemoautotroph. Our results demonstrate that $G$. ferruginea can incorporate glucose, fructose and sucrose (Fig. 1) but the growth rates and the total number of cells at these concentrations of organic substrates did not differ compared to autotrophic growth (Fig. 2). The respiration value of $48 \%$ for glucose corresponds well with Escherichia coli, which respires $50 \%$ of the carbon from glucose as $\mathrm{CO}_{2}$ and uses $50 \%$ for cell material (Gottschalk, 1986), and indicates that glucose was metabolized by $G$. ferruginea. This was confirmed by the microautoradiography, which showed that $96 \%(\mathrm{SD} \pm 4 \%)$ of the population in the stationary phase had incorporated glucose during the time of the growth experiment. The respiration values of fructose $(25 \%)$ and sucrose $(32 \%)$ confirm that the sugars are metabolized and used in cell synthesis. The uptake of glucose, fructose and sucrose indicates that $G$. ferruginea has enzyme systems both for incorporation of glucose and fructose and for cleavage of sucrose to glucose and fructose.

Kelly (1989) stated that the proportion of carbon assimilated from $\mathrm{CO}_{2}$ and organic substrates by mixotrophs is dependent on the organic substrate concentration. It has been suggested that the regulatory mechanism of the organism tends to make most efficient use of available metabolic energy for maximizing total biomass production (Bowien et al., 1987). The regulation of $\mathrm{CO}_{2}$ fixation by autotrophic organisms has been observed as either a decrease in the ribulose-1,5-bisphosphate carboxylase activity (e.g. Tabita \& Lundgren, 1971; Pronk 
et al., 1990) or a decrease in phosphoribulokinase activity (Leadbeater \& Bowien, 1984). There was a significant decrease in $\mathrm{CO}_{2}$ fixation in the mixotrophic experiment with $G$. ferruginea, when $20 \mu \mathrm{M}$-glucose was added to the growth medium (Fig. 4). An increase in the glucose concentration increased the cell carbon content of $G$. ferruginea from glucose (Fig. 3). At 10-25 $\mu \mathrm{M}$-glucose, the amount of cell carbon that originated from glucose was within the calculated carbon content interval. It is energetically more favourable to obtain carbon from organic compounds than from $\mathrm{CO}_{2}$ fixation and it is possible that energy remaining from the iron oxidation is responsible for additional cell synthesis in glucose-grown cultures. This was shown by an increase in cell number in stationary phase from $1 \times 10^{6}$ to $5 \times 10^{6}$ cells ml $^{-1}$ when $20 \mu \mathrm{M}$-glucose was added (Fig. 4). The ability to obtain carbon from both organic compounds and $\mathrm{CO}_{2}$ lends selective and survival advantage to a mixotrophic organism like $G$. ferruginea in the nutrient-poor ground waters where it is found.

We are grateful to Amanda Goodman for valuable comments on the manuscript and we also thank Susanne Ekendahl for her excellent technical assistance. This work was supported by the Swedish Natural Science Research Council, B-BU 8466-102.

\section{References}

Bowien, B., Husemann, R., Klintworth, R. \& Windhövel, U. (1987). Microbial Growth on $C_{1}$-Compounds, pp. 21-27. Dordrecht: Martinus Nijhoff Publishers.

BRoCK, T. D. \& MADIGAN, M. T. (1988). Biology of Microorganisms, pp. 568-571. New Jersey: Prentice-Hall.

BROCK, T. D. \& SCHLEGEL, H. G. (1989). Introduction. In Autotrophic Bacteria, pp. 1-16. Edited by H. G. Schlegel \& B. Bowien. Berlin: Springer-Verlag.

FRY, J. C. (1990). Direct methods and biomass estimation. Methods in Microbiology 22, 41-85.

GotTschalK, G. (1986). Bacterial Metabolism, pp. 12-36. New York: Springer-Verlag.

HallbeCK, L. \& Pedersen, K. (1990). Culture parameters regulating stalk formation and growth rate of Gallionella ferruginea. Journal of General Microbiology 136, 1675-1680.
Hanert, H. H. (1981). The genus Gallionella. In The Procaryotes, pp. 509-515. Edited by M. P. Starr, H. G. Trüper, A. Balows \& H. G. Schlegel. Berlin: Springer-Verlag.

HANERT, H. H. (1989). Budding and/or appendaged bacteria. In Bergey's Manual of Systematic Bacteriology, pp. 1974-1979. Edited by M. P. Staley, M. P. Bryant, N. Pfennig \& J. G. Holt. Baltimore: Williams \& Wilkins.

HobBiE, J. E., DALEY, R. J. \& JASPER, S. (1977). Use of nuclepore filter for counting bacteria by fluorescence microscopy. Applied and Environmental Microbiology 33, 1225-1228.

Huffman, E. W. D., JR (1977). Performance of a new automatic carbon dioxide coulometer. Microchemical Journal 22, 567-573.

Ingraham, L. J., MAaLoe, O. \& NeIdHARDT, F. C. (1983). Growth of the Bacterial Cell, pp. 1-48. Sunderland: Sinauer Associates.

JORGENSEN, B. B. (1989). Biogeochemistry of chemoautotrophic bacteria. In Autotrophic Bacteria, pp. 117-146. Edited by H. G. Schlegel \& B. Bowien. Berlin: Springer-Verlag.

KELLY, D. P. (1989). Physiology and biochemistry of unicellular sulfur bacteria. In Autotrophic Bacteria, pp. 193-218. Edited by H. G. Schlegel \& B. Bowien. Berlin: Springer-Verlag.

KUCERA, S. \& WOLFE, R. S. (1957). A selective enrichment method for Gallionella ferruginea. Journal of Bacteriology 74, 344-349.

Leadbeater, L. \& BowiEn, B. (1984). Control of autotrophic carbon assimilation in Alcaligenes eutrophus by inactivation and reactivation of phosphoribulokinase. Journal of Bacteriology 157, 95-99.

LÜTTERS-CZEKALLA, S. (1990). Lithoautotrophic growth of the iron bacterium Gallionella ferruginea with thiosulfate or sulfide as energy source. Archives of Microbiology 154, 417-421.

Nelson, M. J. K., Terlesky, K. C. \& Ferry, J. G. (1987). Recent developments on the biochemistry of methanogenesis from acetate. In Microbial Growth on $C_{1}$ Compounds, pp. 70-76. Edited by H. W. Verseveld \& J. A. Duine. Dordrecht: Martinus Nijhoff.

Pronk, J. T., Meulenberg, R., Van den Berg, D. J. C., BatenburGVAN DER Vegte, W., Bos, P. \& KuENEN, J. (1990). Mixotrophic and autotrophic growth of Thiobacillus acidopholus on glucose and thiosulfate. Applied and Environmental Microbiology 56, 3395-3401.

Stanier, R. Y., Ingraham, J. I., Wheelis, M. L. \& Painter, P. R. (1989). General Microbiology, pp. 390-391. New Jersey: Prentice Hall.

TABITA, R. \& LUNDGREN, D. G. (1971). Utilization of glucose and the effect of organic compounds on the chemolithotroph Thiobacillus ferrooxidans. Journal of Bacteriology 108, 328-333.

TABOR, P. S. \& NEIHOF, R. A. (1982). Improved microautoradiographic method to determine individual microorganisms active in substrate uptake in natural waters. Applied and Environmental Microbiology 44, 945-953.

WINOGRADSKY, S. (1922). Eisenbakterien als Anorgoxydanten. Zentralblatt für Bakteriologie 57, 1-21.

WoOD, H. G. (1989). Past and present of $\mathrm{CO}_{2}$ utilization. In Autotrophic Bacteria, pp. 33-52. Edited by H. G. Schlegel \& B. Bowien. Berlin: Springer-Verlag. 